\title{
Particulate emissions in an engine fueled with biodiesel/Diesel blends at different fuel injection system configurations
}

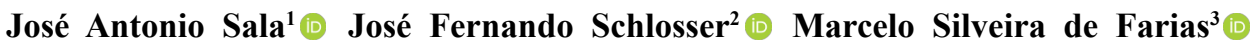 \\ Gilvan Moisés Bertollo ${ }^{4}$ (i) Daniela Herzog ${ }^{2}$ (D)
}

${ }^{1}$ Instituto Federal de Educação, Ciência e Tecnologia Rio Grande do Sul (IFRS), Erechim, RS, Brasil

${ }^{2}$ Departamento de Engenharia Rural (DER), Universidade Federal de Santa Maria (UFSM), Santa Maria, RS, Brasil.

${ }^{3}$ Departamento de Ciências Agronômicas e Ambientais (DCAA), UFSM, 98400-000, Frederico Westphalen, RS, Brasil. E-mail: silveira farias@hotmail.com. *Corresponding author.

${ }^{4}$ Coordenação do Curso de Agronomia, Universidade Tecnológica Federal do Paraná (UTFPR), Campus Santa Helena, Santa Helena, PR, Brasil.

ABSTRACT: The present study aimed to evaluate the particulate emissions in a Diesel engine with an electronic injection system using different biodiesel blends and variations in the fuel injection point and volume, comparing it with the MAR-1 standard. The particulate emissions are analyzed using a two-factor $(12 \times 8)$ completely randomized design that resulted from the interaction of three biodiesel/Diesel blends, two injection point configurations, two fuel injection volumes and eight crankshaft speeds, with 30 repetitions. According to the results, the particulate emissions meet the requirements established by the MAR-I standard when the engine operates at the original factory settings, fueled with blends containing up to 30\% of biodiesel. With the engine angular speed at maximum torque (1,500 rpm), the injection point advanced and the increase in fuel volume, the particulate emissions increased by $115 \%$ and $314 \%$ for the 10 and $30 \%$ biodiesel blends, respectively, regarding the engine operating with the original settings.

Key words: electronic engines, injection point, biofuel, gaseous pollutants.

Emissões de particulados em um motor alimentado com misturas biodiesel/Diesel e sob diferentes configurações do sistema de injeção de combustível

RESUMO: Este trabalho teve como objetivo avaliar e comparar com a norma MAR-I as emissões de particulados em um motor de ciclo Diesel com sistema de injeção eletrônica, submetido à diferentes misturas de biodiesel e alterações no ponto e volume de injeção de combustível. As emissões de particulados foram analisadas com delineamento inteiramente casualizado em esquema bi fatorial (12x8), proveniente da interação de três misturas de biodiesel/Diesel, duas configurações de ponto de injeção, dois volumes de injeção de combustível e oito velocidades de giro do eixo virabrequim, com 30 repetições. Os resultados indicam que, as emissões de particulados atendem às exigências da norma MAR-I quando o motor opera com a regulagem original de fabricação e é alimentado com misturas de até $30 \%$ de biodiesel. Na velocidade angular de torque máximo (1.500 rpm), o adiantamento do ponto de injeção e o aumento do débito de combustivel, para as misturas de 10 e $30 \%$ de biodiesel, aumentam em 115 e 314\%, respectivamente, as emissões de particulados, em relação ao motor na configuração original.

Palavras-chave: motores eletrônicos, ponto de injeção, biocombustivel, gases poluentes.

\section{INTRODUCTION}

Diesel engines have always been associated with the release of environmental pollutants due to the excessive exhaust smoke, especially when operated under heavy loads, at low speeds and fed with fossil fuels. To meet the demand for a reduction in pollutant emissions, studies have been conducted to develop and use various alternative fuels (PERIN et al., 2015; ESTRADA et al., 2016; FARIAS et al., 2019).

Various studies have discussed the benefits of using biodiesel from diverse sources, pure or blended with mineral Diesel oil. The use of this alternative fuel promotes the reduction of carbon dioxide, hydrocarbon, and particulate emissions (JIAQIANG et al., 2017; DUDA et al., 2018). Particulates are small solid particles suspended in the atmosphere that, when smaller than $10 \mu \mathrm{m}$, can cause health problems due to the possibility of penetrating the organism when the particles are inhaled (EPA, 2014).

In conclusion, one of the alternatives for reducing pollutant emissions is to partially replace conventional Diesel with biodiesel (AZAM et al., 2019; HUANG et al., 2019). Additionally, owing

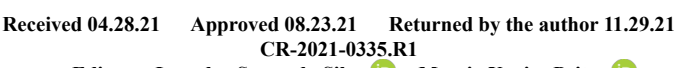


to its higher lubricity, biodiesel is adequate for the lubrication of friction pairs in the engine's fuel injection system. However, it intensifies lubricant degradation due to its dilution with fuel, which is associated with the higher viscosity and lower volatility of biodiesel compared to Diesel oil (PEREIRA et al., 2020).

Many environmental protection agencies worldwide have defined restrictions regarding the acceptable amount of pollutants in the atmosphere (KUMAR et al., 2020). The primary pollutant emission standards are the North American (TIER, stage 4B) and the European (EURO, stage V). In the United States, the federal control law for off-road vehicles was adopted in 1994 (DALLMANN \& MENON, 2016), whereas in Europe, the first law was enacted in 1997 (KIM et al., 2017).

In Brazil, the restrictions began in 1986 with the creation of the Motor Vehicle Air Pollution Control Program (Programa de Controle da Poluição do Ar por Veículos Automotores - PROCONVE). With resolution N. 433 of July 13, 2011, by the National Environment Council, the Brazilian law on emissions for Agricultural and Road Machinery (Máquinas Agrícolas e Rodoviárias - MAR-I) was created (BRASIL, 2011). Although regulations existed for over 30 years until the end of 2014, there was no limit set with regard to the agricultural machinery emissions; this caused most machinery, which were sold, to have engines with the same technology used in the 80 s.

The emission control standards represent significant challenges for developing less polluting Diesel engines (DHANASEKARAN etal., 2017). These challenges have been solved using technologies such as the electronic fuel injection system, which provides more accurate injection time and pressure (KUMAR et al., 2020). The technology is currently a crucial part of the national and international offer of agricultural tractors.

Few studies on agricultural engine emissions have been influenced by the variations in the electronic injection system in Brazil. Thus, the current study aimed to evaluate the particulate emissions in a Diesel engine with an electronic injection system using different biodiesel blends and variations in the fuel injection point and volume, comparing it with the MAR-1 standard.

\section{MATERIALS AND METHODS}

\section{Engine research}

Massey Ferguson MF 6713R tractor (Massey Ferguson, Canoas, Brazil) was used in the experiment, equipped with a four-stroke Diesel engine manufactured by AGCO Power, model 44 CWC3.1164, with four cylinders, displaced volume of 4,397 $\mathrm{cm}^{3}$ and overfed with a turbocharger and an intercooler. In previous dynamometric tests, the engine, which had been operating for eight hours at the beginning of the study, presented $449.44 \mathrm{Nm}$ of torque at $1,500 \mathrm{rpm}$ and a maximum power of 77.04 $\mathrm{kW}(104.75 \mathrm{cv})$ at $1,806 \mathrm{rpm}$, according to the DIN 70020 standard.

According to the manufacturer, the fuel injection system is electronically managed, manufactured by Bosch Common Rail, with a maximum injection pressure of 1,800 bar. The Diesel oil used in the experiment was S10 and sold by the local supply network. According to the current Brazilian law, this oil contains 10\% biodiesel.

\section{Data acquisition}

The data on particulates was obtained using the SAXON opacimeter model Opacilyt 1030, which measures particulates according to the partial flow opacity of gases, using the MW IELD 01030 software. The measurement is performed using the light absorption coefficient ( $\mathrm{k}$ value), which provides the particulate matter emissions (PM) in g. $(\mathrm{kW} . \mathrm{h})^{-1}$ using the mathematical equation presented below (PILUSA et al., 2012).

$\mathrm{PM}=0.47142 \mathrm{X} k$

Where:

PM - Pollutant mass in g.(kW.h $)^{-1}$;

$\mathrm{k}$ - Particulate matter $\left(\mathrm{m}^{-1}\right)$;

0.47142 - Constant.

The exhaust gas temperature was considered because the MAR-I standard provides the total particulate quantity instead of the volumetric concentration. Thus, the temperature data $\left({ }^{\circ} \mathrm{C}\right)$ was collected using a k-type thermocouple at the same point where the opacimeter probe was set up.

The engine's breaking was performed using the EGGERS model PT 301 MES dynamometric brakes coupled to the power take-off of the tractor. The equipment was set up using the EGGERS Power Control software to subject the engine to a series of loads that cause successive reductions of $100 \mathrm{rpm}$ in the engine angular speed, starting with the first data collection at 2,000 rpm until the last at 1,300 rpm (Figure 1). Before the tests, all the necessary adjustments were performed according to the instructions contained in Code 2 (OECD, 2014) and the engine governor control was positioned at full-load operation.

\section{Used fuels}

The biodiesel and Diesel oil blends were prepared at the experiment site using the volumetric blending method. According to the current Brazilian 


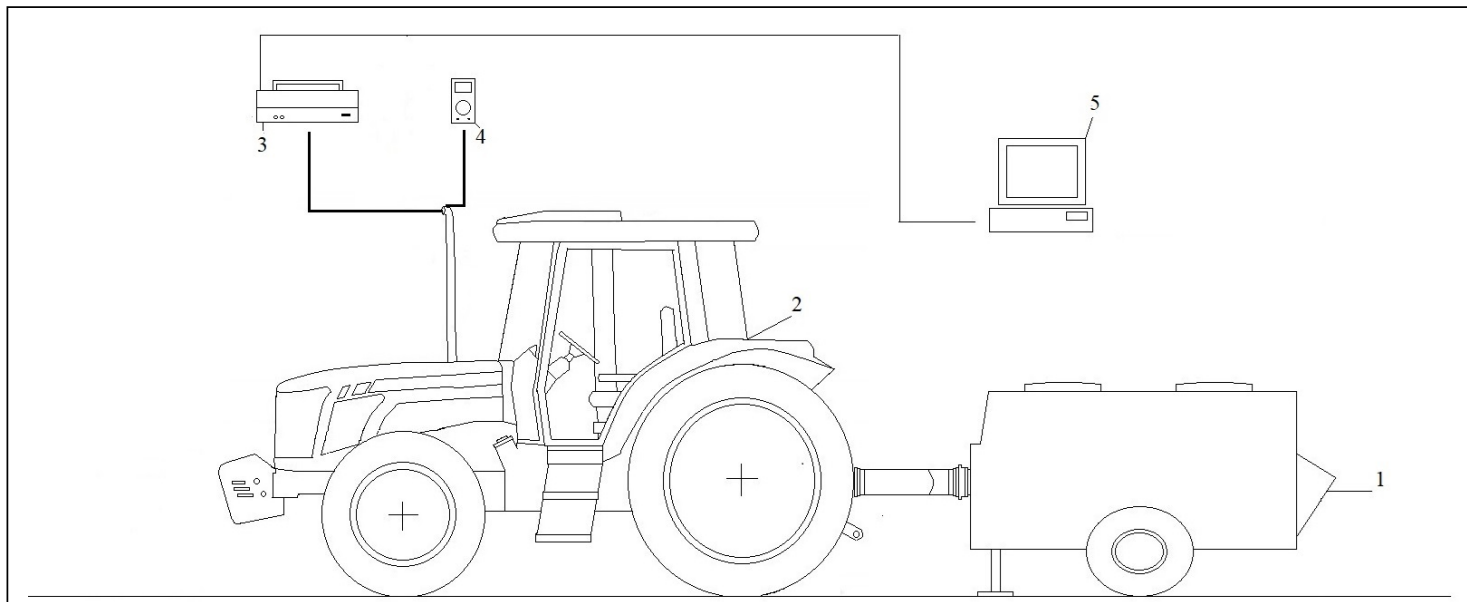

Figure 1 - Schematic representation of the experiment to obtain the particulate matter emissions (1. dynamometric brake, 2 . agricultural engine, 3. opacimeter, 4. k-type thermocouple, 5. software MW IELD 01030).

law, the base fuel was the S10 Diesel containing $10 \%$ of biodiesel (B10). To formulate the B20 and B30 blends, B100 biodiesel from soybean oil was used, according to the ANP resolution $\mathrm{n}$. 45 of 2014 . Thus, the B20 fuel was added with $125 \mathrm{ml}$ of B100 biodiesel for each liter of B10 Diesel; in turn, the B30 fuel was added with $285.7 \mathrm{ml}$ of B100 biodiesel for each liter of B10 Diesel. The volumetric densities of the three fuels, namely B20, B20, and B30, used were 0.844, 0.849, and $0.854 \mathrm{~kg} \mathrm{~L}^{-1}$, respectively.

\section{Fuel injection system settings}

The fuel injection point was modified by changing the location where the crankshaft position sensor was attached using eccentric bushings (Figure 2). This variation caused the phonic wheel reading to be advanced by $2.5^{\circ}$, thereby predicting the fuel injection curve in its entirety as compared to the original condition.

The amount of fuel volume injected at each stroke depends on the Common Rail pressure and the injection nozzle opening time, which are controlled by the Electronic Control Unit (ECU). Considering that the manufacturer blocks this unit to prevent variations, a signal emulator of the fuel pressure sensor was used.

The emulator uses a free hardware electronic prototyping platform and operates by converting the analogous signal from the sensor into an output signal with Pulse-Width Modulation (PWM). Resistors and capacitors then filter the PWM signal to form a signal that closely resembles an analogous signal. Lastly, a $-7 \%$ offset is applied to this filtered signal before sending it to the ECU. With the signal modified as described, the ECU interprets that the fuel pressure in the Common Rail is lower than the real value. Therefore, it increases the injector opening time, and consequently, the injected fuel volume.

Hence, two levels were established for each factor. The injection point factor was composed based on the original point condition (OP), established by the manufacturer, and the injection point advance (PA). The injected volume factor also comprised the original factory volume condition (OV) and the additional injected fuel volume (AV).

\section{Test method and procedure}

Before the tests and data collection, the engine was warmed up for $30 \mathrm{~min}$ until it reached the permanent regimen temperature. For this, a partial load was applied to the engine using the dynamometer. The same procedure was repeated for every variation in the engine fuel injection system settings.

The data collection rate was $1 \mathrm{~Hz}$. For the statistical analysis of the results, the data collected at the angular speeds in the range 2,000 rpm to $1,300 \mathrm{rpm}$ were considered; further, only the last 30 data (repetitions) at each engine angular speed were considered.

After measuring the particulate emission levels under the original engine factory conditions, with B10, B20, and B30 fuels, alterations were made in the engine fuel injection volume and point.

\section{Experimental and statistical procedures}

The emissions were analyzed by applying a two-factor completely randomized design $(12 \times 8)$ that 
resulted from the interaction of the following factors: fuels and fuel injection system settings (biodiesel blended with Diesel oil - B10, B20, and B30; fuel injection point - OP and PA; and fuel injection volume $-\mathrm{OV}$ and $\mathrm{AV}$ ); and engine angular speeds (from 2,000 to $1,300 \mathrm{rpm}$ ), with 30 repetitions. The results were subjected to a variance analysis $(\mathrm{P} \leq 0.05)$. In the case of significance, the means of the qualitative data were analyzed by Tukey's test $(\mathrm{P} \leq 0.05)$ and the means of the quantitative data by regression using the Sisvar software (FERREIRA, 2014).

\section{RESULTS AND DISCUSSION}

The analysis of the particulate emissions for the original engine electronic management condition revealed values below the maximum limits established by the MAR-I standard for the three evaluated fuel blends. The B20 fuel presented the lowest particulate emissions. PERIN et al. (2015) and ASOKAN et al. (2018) obtained the lowest emission levels with the $20 \%$ biodiesel blend.

The change in the electronic engine mapping led to an increase in the particulate emissions, especially in tests with $\mathrm{B} 10+\mathrm{AV}$ and $\mathrm{B} 10+\mathrm{PA}+\mathrm{AV}$, characterized by the more significant amount of fuel injected in the combustion chamber (Figure 3a). In turn, the B10+PA condition presented a tendency toward lower emissions, with significant results only for engine speeds above 1,600 rpm (Table 1). For all engine angular speeds evaluated for this fuel, the particulate emission levels remained below the maximum limit established by the Brazilian law on emissions.

For the B20 fuel, all the analyzed variations resulted in higher emission levels when compared to the original scanning condition (Figure $3 b$ ). The higher concentrations occurred at conditions with the most significant amounts of injected fuel, especially at lower engine angular speeds. The injection point advance (B20+PA) presented a tendency toward higher particulate levels for high engine angular speeds. Although the emissions increased, the tests with the $20 \%$ biodiesel blend remained within the acceptable limit established by the standard.

The fuel injection strategy is a crucial parameter in Diesel engines and is used to optimize combustion, performance, and gaseous pollutant emissions (AGARWAL et al., 2013). By studying the effect of injection time on Diesel engine emissions, Qi

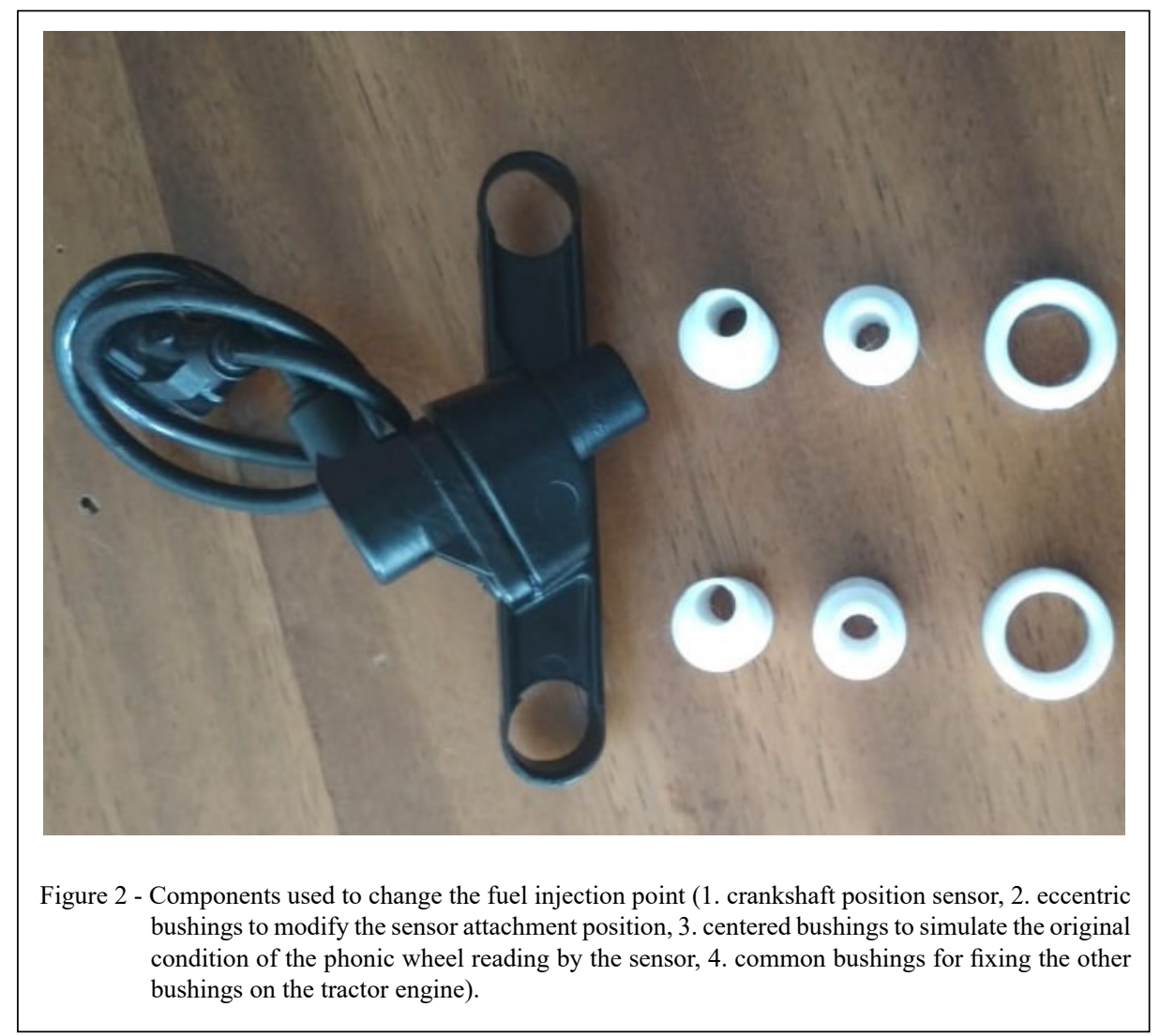

Ciência Rural, v.52, n.8, 2022. 


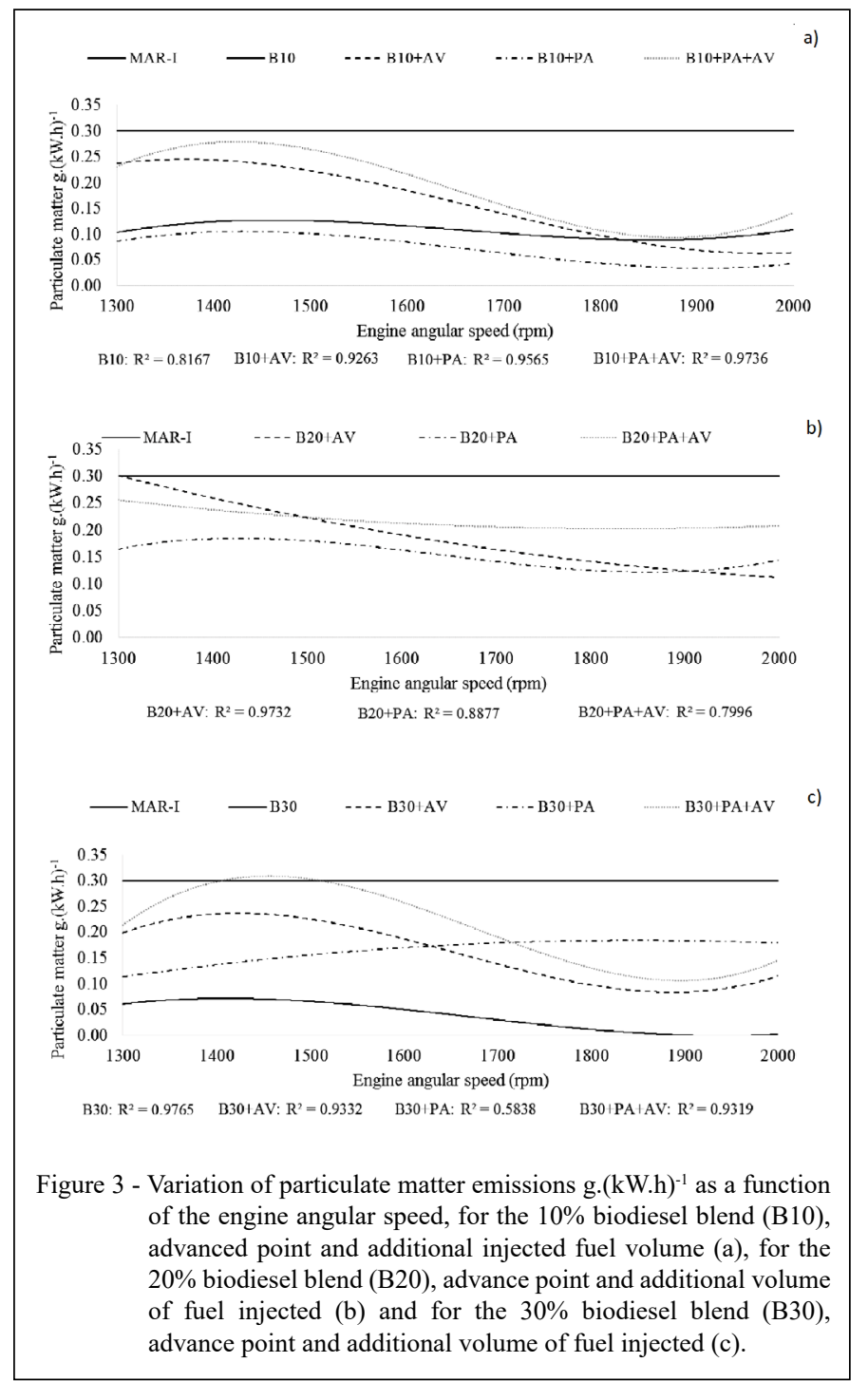

et al. (2011) observed a reduction in $\mathrm{NO}_{\mathrm{x}}$ emissions, whereas the particulate emissions did not vary.

Lastly, the $30 \%$ biodiesel blend at the original engine injection settings presented the lowest particulate emissions (Figure 3c). The use of biodiesel blended with conventional Diesel oil reduces particulate emissions and leading pollutant gases (DUDA et al., 2018). According to TABILE et al. (2009), the emission of particulate matter reduces when a biodiesel content of up to $75 \%$ ratio is used. The absence of sulfur in biofuel partially accounts for this reduction. According to MAZIERO et al. (2006), under certain engine operational conditions, during the late combustion phase, sulfur shares the available oxygen with the carbon from the partial fuel combustion, thereby increasing the production of particulates.
In turn, the tests with B30+PA presented an increase in the emitted particulate content, especially at higher engine angular speeds. The tests with $\mathrm{B} 30+\mathrm{AV}$ and $\mathrm{B} 30+\mathrm{PA}+\mathrm{AV}$ showed similar results; however, they presented higher emission levels across the evaluated range when the injection point was advanced. Although the injection was initiated earlier, the addition of biodiesel causes a delay in the ignition of all engine loads due to the higher cetane number of biodiesel (WANG et al., 2010). Most importantly, the 1,400 rpm point for the $\mathrm{B} 30+\mathrm{PA}+\mathrm{AV}$ test was the only case that exceeded the maximum limit of the particulate emissions established by the MAR-I Brazilian standard.

Particulates are the visible fraction of gases emitted by the exhaust system. They are produced due to problems in the adjustment of excess air during 
Table 1 - Particulate matter emissions g. $(\mathrm{kW} . \mathrm{h})^{-1}$ as a function of the engine angular speed, for three blends of biodiesel in mineral diesel oil, two points and two volumes of fuel injection.

\begin{tabular}{|c|c|c|c|c|c|c|c|c|}
\hline \multirow[t]{2}{*}{ Factors } & \multicolumn{8}{|c|}{--------------------------------------------------------Engine angular speed (rpm)---- } \\
\hline & 1,300 & 1,400 & 1,500 & 1,600 & 1,700 & 1,800 & 1,900 & 2,000 \\
\hline \multicolumn{9}{|c|}{ } \\
\hline OPOV & $0.11^{\mathrm{f}^{*}}$ & $0.11^{\mathrm{d}}$ & $0.13^{\mathrm{d}}$ & $0.12^{\mathrm{d}}$ & $0.11^{\mathrm{f}}$ & $0.09^{\mathrm{e}}$ & $0.08^{\mathrm{cd}}$ & $0.11^{\mathrm{c}}$ \\
\hline PA & $0.09^{\mathrm{fg}}$ & $0.09^{\text {de }}$ & $0.11^{\mathrm{d}}$ & $0.08^{\mathrm{e}}$ & $0.07^{\mathrm{g}}$ & $0.04^{\mathrm{f}}$ & $0.03^{\mathrm{e}}$ & $0.05^{\mathrm{d}}$ \\
\hline AV & $0.24^{\mathrm{bc}}$ & $0.25^{\mathrm{b}}$ & $0.19 b^{c}$ & $0.23^{\mathrm{b}}$ & $0.12^{\mathrm{def}}$ & $0.10^{\text {de }}$ & $0.07^{\mathrm{d}}$ & $0.07^{\mathrm{d}}$ \\
\hline PAAV & $0.24^{\text {bc }}$ & $0.26^{\mathrm{b}}$ & $0.28^{\mathrm{a}}$ & $0.22^{\mathrm{b}}$ & $0.14^{\text {cde }}$ & $0.11^{\text {de }}$ & $0.10^{\text {bc }}$ & $0.14^{b c}$ \\
\hline \multicolumn{9}{|c|}{ 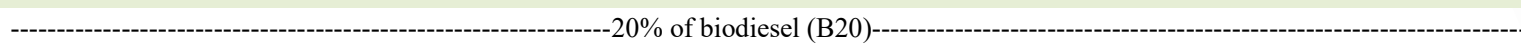 } \\
\hline OPOV & $0.00^{\mathrm{h}}$ & $0.01^{\mathrm{f}}$ & $0.00^{\mathrm{f}}$ & $0.00^{\mathrm{f}}$ & $0.00^{\mathrm{h}}$ & $0.00^{\mathrm{g}}$ & $0.00^{\mathrm{e}}$ & $0.00^{\mathrm{e}}$ \\
\hline PA & $0.17^{\mathrm{e}}$ & $0.18^{\mathrm{c}}$ & $0.19^{c}$ & $0.15^{\mathrm{c}}$ & $0.15^{\mathrm{c}}$ & $0.13^{\mathrm{cd}}$ & $0.11^{\mathrm{bc}}$ & $0.15^{\mathrm{b}}$ \\
\hline $\mathrm{AV}$ & $0.30^{\mathrm{a}}$ & $0.26^{\mathrm{b}}$ & $0.22^{\mathrm{b}}$ & $0.20^{\mathrm{b}}$ & $0.16^{\mathrm{bc}}$ & $0.15^{\mathrm{bc}}$ & $0.10^{\mathrm{bc}}$ & $0.12^{\mathrm{bc}}$ \\
\hline PAAV & $0.25^{\mathrm{b}}$ & $0.26^{\mathrm{b}}$ & $0.22^{\mathrm{b}}$ & $0.21^{\mathrm{b}}$ & $0.21^{\mathrm{a}}$ & $0.21^{\mathrm{a}}$ & $0.19^{\mathrm{a}}$ & $0.22^{\mathrm{a}}$ \\
\hline \multicolumn{9}{|c|}{ 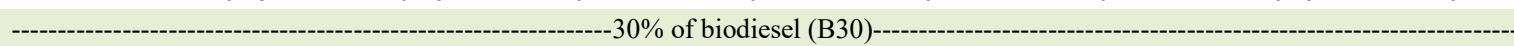 } \\
\hline OPOV & $0.06^{\mathrm{g}}$ & $0.06^{\mathrm{e}}$ & $0.07^{\mathrm{e}}$ & $0.06^{\mathrm{e}}$ & $0.03^{\mathrm{h}}$ & $0.01^{\mathrm{g}}$ & $0.00^{\mathrm{e}}$ & $0.00^{\mathrm{e}}$ \\
\hline PA & $0.12^{\mathrm{f}}$ & $0.11^{\mathrm{d}}$ & $0.20^{\mathrm{bc}}$ & $0.15^{\text {cd }}$ & $0.19^{\mathrm{ab}}$ & $0.17^{\mathrm{b}}$ & $0.18^{\mathrm{a}}$ & $0.19^{\mathrm{a}}$ \\
\hline AV & $0.19^{\text {de }}$ & $0.26^{\mathrm{b}}$ & $0.21^{\mathrm{bc}}$ & $0.20^{\mathrm{b}}$ & $0.12^{\text {ef }}$ & $0.11^{\text {de }}$ & $0.09 b^{\mathrm{cd}}$ & $0.11^{\mathrm{c}}$ \\
\hline PAAV & $0.21^{\mathrm{cd}}$ & $0.31^{\mathrm{a}}$ & $0.29^{\mathrm{a}}$ & $0.28^{\mathrm{a}}$ & $0.15^{\text {cd }}$ & $0.15^{\mathrm{bc}}$ & $0.12^{\mathrm{b}}$ & $0.14^{b c}$ \\
\hline
\end{tabular}

Legend: OPOV - Point and volume in original condition, established by the manufacturer; PA - Advanced point of fuel injection; AV Additional injected fuel volume; PAAV - Advanced point and additional volume of fuel injected. *Averages followed by the same letters in the column do not differ between each other by Tukey test, considering the nominal value of significance at $5 \%$.

combustion, deficiency in the fuel jet pulverization due to inadequate injection pressure or inadequate fuel viscosity, or by low turbulence in the combustion chamber, which prevents each fuel molecule from finding an oxygen molecule (VERGHANINI FILHO, 2016). In the present study, it was found that the particulate emissions significantly reduced compared to original engine settings when the injection point was advanced and a more significant amount of fuel was injected.

The greater the amount of fuel in the air/fuel ratio, the smaller the amount of air and the higher the tendency to form particulates; this is because when air is not in contact with the fuel, combustion does not occur. The engine is designed to operate with a particular standard fuel. Changes in any physical-chemical property of the fuel, for instance, a higher or lower kinetic viscosity and specific mass, can cause changes in the jet distribution and, therefore, the combustion. The tendency is to increase the fuel content in the blend with any increase or decrease in viscosity.

\section{CONCLUSION}

The particulate emissions for an engine operating with an original setting and with blends containing up to $30 \%$ of biodiesel in Diesel oil do not reach the maximum limits of 0.30 g.(kW.h $)^{-1}$ established by the MAR-I Brazilian standard.

The injection point advanced and additional fuel volume injected at the maximum torque speed $(1,500 \mathrm{rpm})$ for the blends containing 10 and $30 \%$ of biodiesel increased the particulate emissions by 115 and $314 \%$, respectively, regarding the original condition.

\section{DECLARATION OF CONFLICT OF INTEREST}

We have no conflict of interest to declare.

\section{ACKNOWLEDGEMENTS}

The authors are grateful to the Conselho Nacional de Desenvolvimento Científico e Tecnológico (CNPq) for research productivity scholarship of the second author; and was financed in part by the Coordenação de Aperfeiçoamento de Pessoal de Nível Superior (CAPES), Brazil - Finance Code 001.

\section{AUTHOR'S CONTRIBUTIONS}

All authors contributed equally for the conception and writing of the manuscript. 


\section{REFERENCES}

AGARWAL, A. K. et al. Effect of fuel injection timing and pressure on combustion, emissions and performance characteristics of a single cylinder diesel engine. Fuel, v.111, p.374-383, 2013. Available from: <https://www.sciencedirect.com/science/article/ abs/pii/S0016236113002044>. Accessed: Apr. 15, 2021. doi: 10.1016/j.fuel.2013.03.016

ASOKAN, M. A. et al. Performance, combustion and emission characteristics of diesel engine fuelled with papaya and watermelon seed oil bio-Diesel/Diesel blends. Energy, v.145, p.238-245, 2018. Available from: <https://www.sciencedirect.com/science/article/ abs/pii/S0360544217321837>. Accessed: Sep. 15, 2020. doi: 10.1016/j.energy.2017.12.140.

AZAM, A. et al. Design, fabrication and implementation of HEOBCU-EGR emission control unit on CI engine and analysis of its effects on regulated gaseous engine emissions. Journal of King Saud University - Engineering Sciences, v.10, p.1-9, 2019. Available from: <https://www.sciencedirect.com/science/ article/pii/S1018363919303253>. Accessed: Sep. 15, 2020. doi: 10.1016/j.jksues.2019.10.002.

BRASIL. Conselho Nacional do Meio Ambiente. Programa de Controle da Poluição do Ar por Veículos Automotores: Resolução No 433. 2011. Available from: <http://www.ibama. gov.br/sophia/cnia/legislacao/CONAMA/RE0433-130711.PDF>. Accessed: Oct. 19, 2021.

DALLMANN, T.; MENON, A. Technology pathways for diesel engines used in non-road vehicles and equipment. Washington: The International Council on Clean Transportation, 2016. 47p. Available from: <https:// theicct.org/sites/default/files/publications/Non-Road-TechPathways white-\%20paper vF ICCT 20160915.pdf $>$. Accessed: Sep. 15,2020 .

DHANASEKARAN, R. et al. A sustainable and eco-friendly fueling approach for direct-injection diesel engines using restaurant yellow grease and n-pentanol in blends with diesel fuel. Fuel, v.193, p.419-431, 2017. Available from: $<$ https://www.sciencedirect.com/science/article/abs/pii/ S0016236116312625>. Accessed: Sep. 15, 2020. doi: 10.1016/j. fuel.2016.12.030.

DUDA, K. et al. Comparison of performance and emissions of a CRDI Diesel engine fuelled with biodiesel of different origin. Fuel, v.212, p.202-222, 2018. Available from: $<$ https://www.sciencedirect.com/science/article/abs/pii/ S0016236117312206>. Accessed: Sep. 15, 2020. doi: 10.1016/j. fuel.2017.09.112.

EPA. Environmental Protection Agency. AIR QUALITY INDEX: A Guide to Air Quality and Your Health. EPA-456/F-14-002 2014. Available from: <http://www.epa.gov/airnow/aqi brochure_02_14.pdf $>$. Accessed: Sep. 19, 2020.

ESTRADA, J. S. et al. Emissions of Diesel cycle engine using biofuels blends. Revista Agrarian, v.9, n.33, p.274-279, 2016. Available from: <http://ojs.ufgd.edu.br/index.php/agrarian/ article/view/4141/3666>. Accessed: Sep. 15, 2020.

FARIAS, M. S. et al. Emissions of an agricultural engine using blends of diesel and hydrous ethanol. Semina: Ciências Agrárias, v.40, n.1, p.7-16, 2019. Available from: $\quad<$ http://www.uel.br/revistas/uel/index.php/semagrarias/ article/view/31707/24982>. Accessed: Sep. 15, 2020. doi: 10.5433/1679-0359.2019v40n1p7.

FERREIRA, D. F. Sisvar: a Guide for its Bootstrap procedures in multiple comparisons. Ciência e Agrotecnologia, v.38, n.2, p.109-112, 2014. Available from: <https://www.scielo.br/pdf/ cagro/v38n2/a01v38n2.pdf $>$. Accessed: Sep. 16, 2020. doi: 10.1590/S1413-70542014000200001.

HUANG, H. Assessment of n-pentanol additive and EGR rates effects on spray characteristics, energy distribution and engine performance. Energy Conversion and Management, v.202, p.1-12, 2019. Available from: <https://www.sciencedirect.com/ science/article/abs/pii/S0196890419312166>. Accessed: Sep. 15, 2020. doi: 10.1016/j.enconman.2019.112210.

JIAQIANG, E. et al. Effect of different technologies on combustion and emissions of the diesel engine fueled with biodiesel: A review. Renewable and Sustainable Energy Reviews, v.80, p.620-647, 2017. Available from: $<$ https://www.sciencedirect.com/science/article/abs/pii/ S136403211730895X>. Accessed: Sep. 15, 2020. doi: 10.1016/j. rser.2017.05.250.

KIM, Y. S. et al. Demand Forecasting for Heavy-Duty Diesel Engines Considering Emission Regulations. Sustainability, v.9, n.2, p.1-16, 2017. Available from: <https://www.mdpi. com/2071-1050/9/2/166>. Accessed: Sep. 15, 2020. doi: $10.3390 /$ su 9020166 .

KUMAR, P. S. et al. Reduction of emissions in a biodieselfueled compression ignition engine using exhaust gas recirculation and selective catalytic reduction techniques. Heat Transfer, v.49, p.3119-3133, 2020. Available from: <https:// onlinelibrary.wiley.com/doi/10.1002/htj.21765>. Accessed: Sep. 15, 2020. doi: 10.1002/htj.21765.

MAZIERO, J. V. G. et al. Evaluation of polluting emissions from a diesel engine using sunflower biodiesel as fuel. Engenharia na Agricultura, v.14, n.4, 287-292, 2006.

OECD. Code 2: Standard code for the official testing of agricultural and forestry tractor performance. Paris, 2014. 104p.

PEREIRA, F. M. et al. Impact of pure biodiesel fuel on the service life of engine-lubricant: A case study. Fuel, v.261, p.1-7, 2020. Available from: <https://www.sciencedirect.com/science/ article/pii/S0016236119317727>. Accessed: Apr. 07, 2021. doi: 10.1016/j.fuel.2019.116418.

PERIN, G. F. et al. Emissions of agricultural engine using different diesel types and biodiesel concentrations in the fuel mixture. Pesquisa Agropecuária Brasileira, v.50, n.12, p.11681176, 2015. Available from: <https://seer.sct.embrapa.br/index. php/pab/article/view/21268/13132>. Accessed: Sep. 15, 2020. doi: 10.1590/S0100-204X2015001200006.

PILUSA, T. J. et al. Reduction of Vehicle Exhaust Emissions from Diesel Engines Using the Whale Concept Filter. Aerosol and Air Quality Research, v.12, n.5, p.994-1006, 2012. Available from: $<$ https://aaqr.org/articles/aaqr-12-04-oa-0100.pdf $>$. Accessed: Jul. 10, 2021. doi: 10.4209/aaqr.2012.04.0100.

QI, D. et al. Effect of EGR and injection timing on combustion and emission characteristics of split injection strategy DI- 
diesel engine fueled with biodiesel. Fuel, v.90, n.5, p.1884-1891, 2011. Available from: <https://www.sciencedirect.com/science/ article/abs/pii/S0016236111000184>. Accessed: Apr. 15, 2021. doi: 10.1016/j.fuel.2011.01.016.

TABILE, R. A. et al. Mamona biodiesel in interior and metropolitan diesel in agricultural tractor. Engenharia Agrícola, v.29, n.3, p.412-423, 2009. Available from: $\quad<$ https://www.scielo.br/pdf/eagri/v29n3/a08v29n3. pdf>. Accessed: Apr. 07, 2021. doi: 10.1590/S010069162009000300008 .

WANG, X. et al. Experimental and analytical study on biodiesel and diesel spray characteristics under ultra-high injection pressure. International Journal Heat Fluid Flow, v.31, n.4, p.659-666, 2010. Available from: <https:/www.sciencedirect.com/science/article/ abs/pii/S0142727X1000069X>. Accessed: Apr. 15, 2021. doi: 10.1016/j.ijheatfluidflow.2010.03.006. 